\title{
Communication/Comunicação
}

\section{Cat infected by a variant of bat rabies virus in a 29-year disease-free urban area of southern Brazil}

\author{
Gato infectado por variante do vírus rábico de morcego em uma área urbana do sul do Brasil \\ há 29 anos livre da doença
}

\author{
Vivien Midori Morikawa ${ }^{1,2}$, Juliano Ribeiro ${ }^{2}$, Alexander Welker Biondo ${ }^{1}$, Anaclete Fellini ${ }^{3}$, Daniele Bier ${ }^{1}$ \\ and Marcelo Beltrão Molento ${ }^{1}$
}

\begin{abstract}
Introduction: After 29 years, rabies was detected in a cat in Curitiba, southern Brazil. Methods: The fluorescent antibody test (FAT) and mouse inoculation test (MIT) were performed on central nervous system (CNS) samples. Results: Direct immunofluorescence was negative, but the biological test was positive and rabies virus was characterized as variant 4 (from Tadarida brasiliensis). Conclusions: Reappearance of rabies in domestic animals warns of sylvatic-aerial risk of infection and the necessity of monitoring bats in historically rabies-free areas.
\end{abstract}

Keywords: Feline rabies. Nonhematophagous bat. Epidemiological surveillance.

\section{RESUMO}

Introdução: Após 29 anos, raiva em um gato foi detectada em Curitiba, sul do Brasil. Métodos: Foram realizados imunofluorescência direta e prova biológica através de inoculação em camundongos para o diagnóstico da raiva. Resultados: A imunofluorescência direta foi negativa, mas a prova biológica foi positiva e o vírus caracterizado como variante 4 (de morcegos não hematófagos). Conclusões: $\mathrm{O}$ reaparecimento da raiva alerta para o risco aéreo-silvestre de infecção e para a necessidade de monitoramento de morcegos em áreas historicamente livres da raiva.

Palavras-chaves: Raiva felina. Morcegos não-hematófagos. Vigilância epidemiológica.

All mammals are susceptible to rabies and transmission in tropical countries involves two major cycles: the urban cycle, in which dogs and cats are the main sources of infection, and the sylvatic, where transmission mainly occurs from bats, monkeys and foxes ${ }^{1,2}$. Mass vaccination campaigns in dogs and cats have strongly reduced rabies throughout Brazil ${ }^{3}$. Meanwhile, cases of rabies transmitted by bats have increased in urban areas as a consequence of the environmental impact of urbanization on bat habitats, the shelter offered by man-made constructions and food from imbalanced urban fauna ${ }^{4}$. Not surprisingly, animal causes of infection in Latin America have switched since 2004 from dogs to bats ${ }^{2}$. The last two cases of human rabies in the State of Paraná, southern Brazil were registered in 1987, with a hematophagous bat (Desmodus rotundus) as agent,

1. Laboratório de Doenças Parasitárias, Departamento de Medicina Veterinária, Universidade Federal do Paraná, Curitiba, PR. 2. Centro de Controle Zoonoses, Secretaria Municipal de Saúde, Curitiba, PR. 3. Laboratório Central do Estado, Secretaria de Saúde do Estado do Paraná, São José dos Pinhais, PR.

Address to: Dra. Vivien Midori Morikawa. Lab. Doenças Parasitárias/Dept ${ }^{\circ}$. Medicina Veterinária/UFPR. Rua dos Funcionários 1540, Cabral, 80035-050 Curitiba, PR, Brasil. Phone: 5541 3350-5618

e-mail: vmorikawa@smma.curitiba.pr.gov.br

Received in $21 / 11 / 2010$

Accepted in 10/01/2011 and in 1975, by a dog in Curitiba ${ }^{5}$. The last canine rabies infection in Curitiba was registered in 1981. Due to rabies control, no current massive rabies vaccination is in effect in Curitiba and the surrounding areas $^{6}$. However, nonhematophagous bats positive for rabies have been recorded annually in recent years (Table 1). The present study reports the first case of cat rabies in Curitiba and surrounding areas for the past 29 years.

Curitiba $\left(25^{\circ} 25^{\prime} 47^{\prime \prime S}, 49^{\circ} 16^{\prime} 19^{\prime \prime} \mathrm{W}\right)$ is the capital of the State of Paraná, southern Brazil, with an estimated population of $1,851,215$ inhabitants, the seventh most populated city in Brazil ${ }^{7}$. On April $20^{\text {th }}$ 2010, the Zoonoses Control Center (CCZV) was informed that a 3 -year-old male cat not vaccinated against rabies had suddenly had a convulsion and died. Another 8 cats with free-access to the street and 2 dogs lived in the same household. These animals presented no clinical signs compatible with rabies and were vaccinated. The owner had tried to medicate the cat, during which she was bitten on the hand. Despite no definitive diagnosis at the time, the woman was submitted to the standard postinfection protocol for high rabies risk, anti-serum therapy and five doses of cell culture anti-rabies vaccine on days $0,3,7,14$ and 28, by the local primary healthcare clinic.

Central nervous system tissue from the cat was sent to the Paraná State Central Reference Laboratory (LACEN-PR), where fluorescent antibody test $(\text { FAT })^{8}$ using a panel of monoclonal antibodies proved to be negative. However, the Biological Test by intracerebral inoculation in mice ${ }^{9}$ was positive on day 17 out of a total of 21 days, indicating a viral strain with a prolonged incubation period. The owner was notified and local health authorities monitored the complete vaccination protocol and clinical status of the patient. Based on a monoclonal antibody panel, the virus isolated was characterized at the Pasteur Institute of Sao Paulo as variant 4, compatible with isolates from insectivorous bat Tadarida brasiliensis ${ }^{10}$.

TABLE 1 - Occurrence of nonhematophagous bats positive for rabies in Curitiba since 2006.

\begin{tabular}{lccc}
\hline Year & Location (neighborhood) & Bat species & Habit \\
\hline 2006 & Bairro Alto (1) & Artibeus lituratus & frugivores \\
\hline 2007 & Santa Felicidade (2) & Tadarida brasiliensis & insectivores \\
\hline 2008 & Orleans (3) & Myotis nigricans & insectivores \\
\hline 2009 & Portão (4) & Tadarida brasiliensis & insectivores \\
\hline 2009 & Centro (downtown) (5) & Myotis nigricans & insectivores \\
\hline 2010 & São Lourenço (6) & Sturnira sp & insectivores \\
\hline
\end{tabular}

Source: Centro de Saúde Ambiental/Secretaria Municipal de Saúde, 2010. Numbers inside parenthesis (1 to 6) are geo-referenced on the city map (Figure 1). 


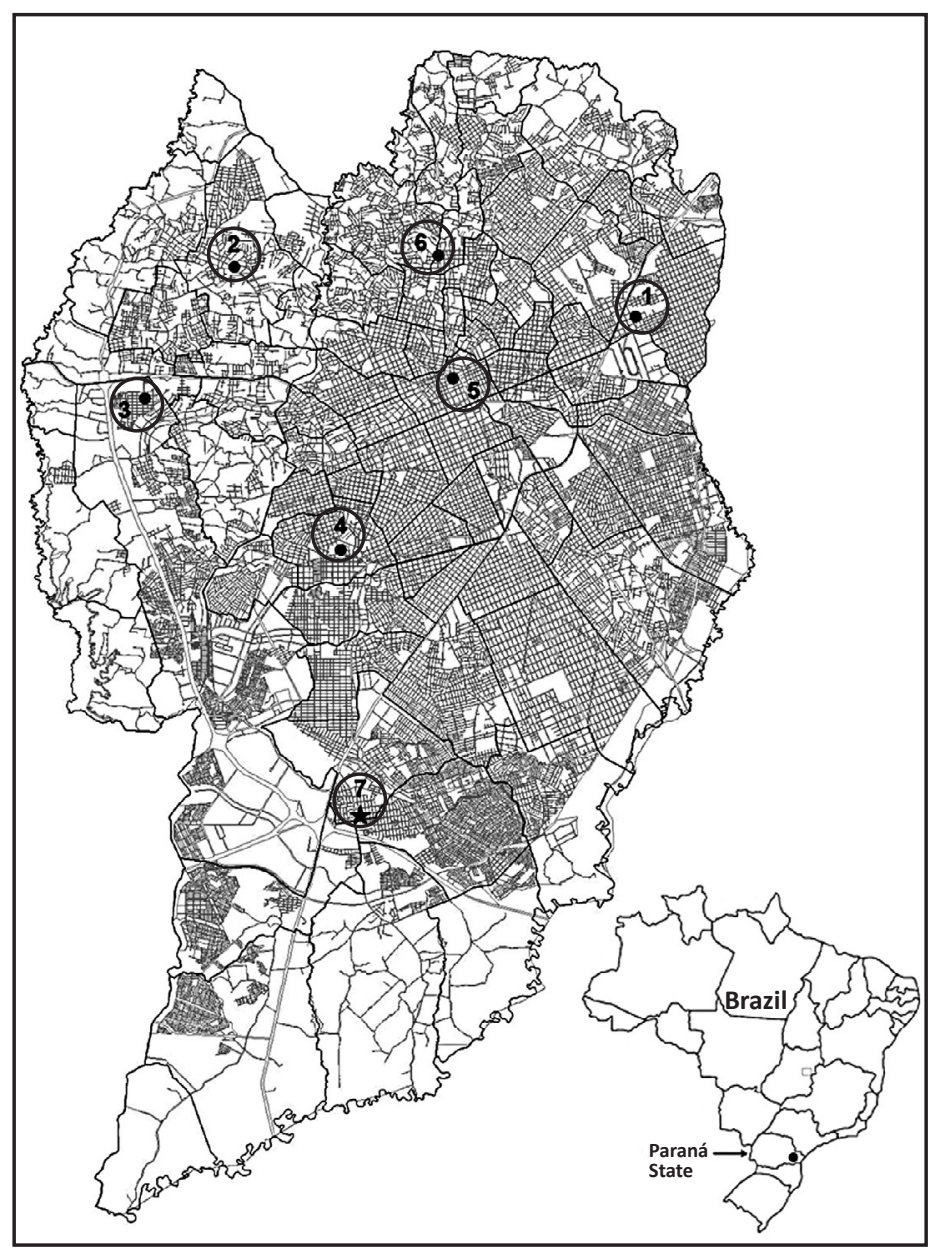

FIGURE 1 - Urbanization map of the City of Curitiba showing the location of six bats ( 1 to 6) and one cat (7) positive for rabies from 2006 to 2010 . Note that the rabiespositive animals were distributed within the city limits, showing that the entire city may be exposed to sylvatic-aerial virus infection.

Massive house to house vaccination was immediately initiated by the CCZV in a $1 \mathrm{~km}$ diameter, such that a total of 874 dogs and 49 cats were vaccinated. Even though the source of cat infection was not identified, a nonhematophagous bat was probably the source of infection, which may currently represent the most dangerous species for human rabies infection. In 2009 and during the first four months of 2010, the Ministry of Health reported a total of 16 and 13 hematophagous and 165 and 114 nonhematophagous bats positive for rabies, respectively ${ }^{11}$. Although anti-vampire paste and mass capture/euthanasia have been reported as efficient at controlling the spread of hematophagous bat rabies ${ }^{3}$, these strategies applied to nonhematophagous bats may lead to species extinction; moreover, nonhematophagous bats are protected by the Brazilian Environmental Laws $^{12}$. The recent capture, euthanasia and brain DIF testing of 200 T. brasiliensis bats in Curitiba in 2009 due to a rabies positive bat in a nearby colony resulted in all negative results, showing that geographical proximity may not indicate the source of infection ${ }^{6}$. A recent study has shown that commercial inactivated rabies vaccine immunoprotected the bat $T$. brasiliensis for over a year, suggesting that massive bat vaccination may be an alternative prevention program ${ }^{10}$. Regardless, active surveillance for rabies involving continuous monitoring of such populations should be conducted in urban areas of large Brazilian cities.

In conclusion, historically rabies-free urban areas among dogs and cats may be exposed to new disease cycles, sylvatic-aerial, as a result of recent changes in nonhematophagous bat behavior. Reemerging cases of rabies in disease-free urban areas warns of the importance of mass vaccination of dogs and cats, in association with continuous monitoring of nonhematophagous bats found during the daytime or in unexpected locations. Finally, negative DIF results for rabies must always be followed by at least 21-day biological testing in mice.

\section{ACKNOWLEDGMENTS}

The authors kindly thank the Pasteur Institute of the State of São Paulo for their diagnostic support regarding rabies virus characterization and the Epidemiology Center of the Municipal Health Secretariat of Curitiba for providing epidemiological data.

\section{CONFLICT OF INTEREST}

The authors declare that there is no conflict of interest.

\section{REFERENCES}

1. Castilho JG, Canello FM, Scheffer KC, Achkar SM, Carrieri ML, Kotait I. Antigenic and genetic characterization of the first rabies virus isolated from the bat Eumopsperotisin Brazil. Rev Inst Med Trop Sao Paulo 2008; 50:95-99.

2. Ministério da Saúde. Guide to Epidemiological Surveillance. $6^{\text {th }}$ ed. Brasília: Secretaria de Vigilância em Saúde; 2005.

3. Kotait I, Aguiar EAC, Carrieri ML, Harmani NMS. Bats Management in urban areas. Brazil: Pasteur Institute; 2003.

4. Sodré MM, Gama AR, Almeida MF. Updated list of bat species positive for rabies in Brazil. Rev Inst Med Trop Sao Paulo 2010; 52:75-81.

5. Secretaria Estadual de Saúde do Paraná. Série Histórica - Raiva humana, 1986 -2008 [Internet]. 2010 - [cited 2010 Aug 20]. Available from: http://www. saude.pr.gov.br/arquivos/File/zoonoses_intoxicacoes/raiva/SH_Raiva_ humana_1986_a_2008.pdf/.

6. Secretaria Estadual de Saúde do Paraná. Série histórica da distribuição de casos de Raiva Canina/Felina e Humana, Paraná - 1955-2007 [Internet]. 2010 - [cited 2010 Aug 20]. Available from: http://www.saude.pr.gov.br/ modules/conteudo/conteudo.php?conteudo=1435/.

7. Population estimates for Curitiba [Internet]. Brasília (DF): Instituto Brasileiro de Geografia e Estatística. 2009 - [cited 2010 Aug 20]. Available from: http:// www.ibge.gov.br/home/estatistica/populacao/estimativa2009/default. $\operatorname{shtm} /$.

8. Dean DJ, Abelseth MK, Atanasiu P. The fluorescent antibody test. In: Meslin FX, Kaplan MM, Koprowski H, editors. Laboratory techniques in rabies. Geneva: World Health Organization 1996. p. 88-95.

9. Koprowski H. The mouse inoculation test. In: Meslin FX, Kaplan MM, KoprowskiH, editors. Laboratory techniques in rabies. Geneva: World Health Organization; 1996. p. 80-87.

10. Favoretto SR, Carrieri ML, Cunha EM, Aguiar EA, Silva LH, Sodre MM, et al. Antigenic typing of Brazilian rabies virus samples isolated from animals and humans, 1989-2000. Rev Inst Med Trop 2002; 44:91-95.

11. Ministério da Saúde. Secretaria de Vigilância em Saúde [Internet]. Brasília (DF): Ministério da Saúde. 2010 [uptaded: 2010 Aug 29; cited 2010 Aug 29]. Available from: http://portal.saude.gov.br/portal/saude/profissional/ area.cfm?id_area $=1567 /$.

12. Lei $n^{\circ} .9605$. Dispõe sobre as sanções penais e administrativas derivadas de condutas e atividades lesivas ao meio ambiente, e dá outras providências (Feb 12, 1998). [cited 2010 Aug 20]. Available from: http://www.planalto. gov.br/ccivil_03/Leis/L9605.htm. 